\title{
Effect of Different Bedding Materials on the Hematological and Serum Biochemical Parameters of Broiler Chickens
}

\author{
Gana James*, Danwake Jibrin Garba, Adekojo Solomon Adeolu, Zarma Adamu, and Zakari Mamma \\ Federal College of Education, School of Vocational Education, Department of Agricultural Education, P.M.B.39. Kontagora, Niger State. Nigeria \\ *Corresponding author's Email: jamesgana38@ gmail.com; ORCID: 0000-0001-9415-5297
}

Received: 03 Apr. 2019

Accepted: 03 May. 2019

\begin{abstract}
The aim of the present study was to determine the effect of different bedding materials on the, hematological and serum biochemical parameters of the broiler chickens. A completely randomized design was employed for the research in which the treatment were five bedding materials (rice hulls, groundnut hulls, wood shaving, sharp sand and control). The treatments were replicated three times each with ten birds in each experimental unit. The birds were brooded for two weeks before the experiment begin. The blood samples were collected at day 56 of experiment for hematological and serum biochemical analysis. There was no significant difference in the glucose, serum total protein, globulin, calcium, sodium, total bilirubin, conjugated bilirubin, and serum alanine transferase, but there was a significant difference in serum cholesterol, albumin, bicarbonate and serum aspartate transferase within the groups. The findings also indicated in the hematological parameters that bedding materials caused significant difference in the hemoglobin content, white blood cell count and mean corpuscular hemoglobin, but no significant differences in the other parameters (Heterophils, monocytes, basophils, lymphocytes, mean cell volume and packed cell volume) were seen. The results suggested that rice, hulls, groundnut hulls and sharp sand can serve appropriately as bedding materials for broiler production, with compatible effects on serum biochemical and hematological parameters.
\end{abstract}

Keywords: Bedding materials, Broilers, Hematology, Serum biochemistry

\section{INTRODUCTION}

Poultry litter is used in confined buildings met for raising broilers, turkeys and other birds. The bedding materials such as wood shavings sawdust, peanut hulls, shredded sugarcane, straw, sand and other dry, absorbent, low-cost organic materials. The main function of bedding materials is to help in the absorption's moisture, preventing the excess production of ammonia and harmful pathogens (Monira et al., 2003).

The materials used as bedding can also have a significant impact on carcass quality and bird's performance as well as on their biochemical characteristics. Some specific procedures must be adhered, to properly maintain the litter and maximize the health and productivity of the birds raised on it (Monira et al., 2003).

The poultry usually grown on dirty floors with some type of bedding material. Concrete floors and some specialized raised flooring are used at some facilities. Most of poultry flocks are raised on the floor with a layer of bedding called, "litter," spread over the top of the floor. Unlike livestock where bedding material is typically clean and unused, in poultry flocks the term bedding material can also mean used bedding material that includes manure, spilled feed, water and feathers. Good litter should be nontoxic to the birds, be free of contaminants, such as pesticides and metals, be very absorbent with a short drying time and be readily available and relatively inexpensive (Monira et al., 2003). The purpose of using litter on floor is to absorb moisture from birds' droppings in order to keep the floor reasonably dry and ensure comfortable conditions for birds. It also gives birds a suitable medium on which feeding, watering and other management practices are carried out. Sawdust, rice husk, sugarcane bagasse, chopped straw, paper and sand amongst others are the common types of litter used in poultry houses throughout Nigeria (Monira et al., 2003).

The considerable individual differences in biochemical indices in birds are the main reason for the wide physiological ranges specified for chickens (Pedersen et al., 2000). The major factors for successful poultry production are high genetic potential, balanced nutrition and health maintenance (Horsted and Hermansen, 2007). Their values are influenced by species, age, sex, 
season, geographic region, nutrition, and physiological condition. They are also indicators of the health of birds housed in cage systems. Variables such as total protein, albumin, cholesterol, glucose, calcium, phosphorus, uric acid, aspartate aminotransferase, lactate dehydrogenase, and lactate are commonly measured biochemical characteristics for poultry (Hrabčáková et al., 2014).

It has been noted that significant changes in the serum biochemical parameters can be done to assess the both pathological and nutritional status of animals (Akpodiete and Ologbodo, 1998). Serum concentrations of glucose, cholesterol, triglyceride and uric acid level have been reported to be significantly affected by different feeding treatments, whereas total protein, albumin and creatinine level were not significantly affected by the treatments (Ibrahim and Albokhadaim, 2016). Serum total protein and albumin have been reported to be directly related to protein intake and quality (Onifade, 1998).

Biochemical valuables can be used to confirm the maturity and to monitor any changes in the quality of water and related soils (Paria, 2014). The evaluation of hematology and serum biochemistry in birds allows for the determinations of metabolic changes due to endo- and exogenous factors including the genetic type, husbandry conditions, season, sex and age (Ross el at., 1978; Bowes et a1., 1989; Melluziet al., 1992; Krasnodêbska et al., 2000; Harr, 2002; Juraniet al., 2004; Rajmanet al., 2006).

Therefore, the objectives of the present study were to evaluate the hematological and serum biochemical parameters of broiler's chickens reared in different bedding materials.

\section{MATERIALS AND METHODS}

The study was conducted at the poultry house in the research and teaching farm of the Department of Agricultural Education of Federal College of Education, Kontagora, Niger State Nigeria. Geographically, Kontagora is located at latitude $10^{0} 24^{\prime} 1$ " North and longitude $5^{0} 28^{\prime} 1$ " East and at an elevation of $335 \mathrm{~m}$ above sea level (Niger State Bureau of statistics, 2011). The birds (broilers) Arbor acre breedwas purchased at day old from Top Link, an accredited poultry hatchery based in Ibadan, Nigeria. They were fed with top feed at day old to the eight weeks, vaccines, antibiotics and anticoccidial were the main routine drugs used for the preventives measures

A Completely Randomized Design (CRD) was used for present study. Five bedding materials (rice hulls, groundnut hulls, Wood Shavings (WS), sharp sand and control, concrete floor) were utilized. The treatments (bedding materials) were replicated three times each, that is, there were fifteen experimental units. Ten birds were placed in each experimental unit, to get a total number of 150birds that have been brooded from day old to two weeks of age.

The blood was collected at day 56 (eighth week) of the experiment. Blood sample was collected from the wing (brachial vein) and neck slitting of bird per replicate. $5 \mathrm{ml}$ of blood was collected from one bird per replicate into a tube containing Ethylene Diamine Tetra Acetate (EDTA) to determine hematological parameters (packed cell volume, white blood cell, Haemoglobin, Red blood cell, Neutrophil, lymphocyte, Eosinophil, Basophile, monocytes and conjugated billirubin) while another $5 \mathrm{ml}$ was collected to determine some serum biochemical parameters $\left(\mathrm{Ca}^{++}, \mathrm{Na}^{++}\right.$, Bicarbonate, Glucose, cholesterol, Total protein, Albumin, Globulin, Total billirubin, Conjugated billirubin, Serum glutamic pyruvic transaminase, serum glutamic oxaloacetic transaminase, and Alkaline phosphate.

\section{Packed cell volume}

The percentage of Packed Cell Volume (PCV) in the blood was determined using the haematocrit centrifuge method as described by Dacie and Lewis (1984; 1995). A capillary tube was dipped into sample to fill it to about three-quarter length. Excess blood on the side of the capillary tube was wiped off in other to keep accurate reading. One end of the tube was sealed over a Bunsen burner. The capillary tube was put into a microhaematocrit reader and the level of the packed cell was regarded as the PCV.

\section{Red blood cell}

Blood was diluted with $0.9 \% \mathrm{NaCl}$. The diluted blood was mounted on a haemocytometer and the number of erythrocytes in the cream scribed volume $\left(0.02 \mathrm{~mm}^{3)}\right.$ was counted microscopically. Calculated erythrocytes were expressed in million per cubic meter (Jain, 1986). $\mathrm{MCHC}=\mathrm{Hb} / \mathrm{PCV}($ grams/litre $)$.

\section{White blood cell}

The estimate of the total blood cells was carried out immediately after collection of blood sample from experimental animals using Neubauer haemocytometer counting chamber (Jain, 1986). From blood sample of test animals $2 \mathrm{ml}$ of blood sample was pipette and mixed with $4 \mathrm{ml}$ of White Blood Cell (WBC) diluting fluid (WBC fluid made up of $3 \%$ aqueous solution of acetic acid and $1 \%$ gentian violet) (Jain,1986). The sample was then put into the haemocytometer and cell counted and expressed as $10^{9}$ WBC per liter of blood. 


\section{Haemoglobin}

The Haemoglobin $(\mathrm{Hb})$ concentration of each blood sample was determined by cyanmethaemoglobin method as described by Jain (1986). From each blood sample of experimental animal, $20 \mu 1$ of blood was mixed with $4 \mathrm{ml}$ of modified Drabkin's solution, Drabkin's solution was prepared by mixing $200 \mathrm{mg}$ potassium ferricynide, $50 \mathrm{mg}$ potassium cyanide and $140 \mathrm{mg}$ potassium dihydrogen phosphate; volume was made up to 1 liter with distilled water and $\mathrm{pH}$ adjusted to 7.0). The mixture of blood sample of experimental animal and Drabkin's solution was allowed to stand for 3 minutes before reading the $\mathrm{Hb}$ concentration using a spectrophotometer at wavelength of $540 \mathrm{~nm}$. The actual value of $\mathrm{Hb}$ was extrapolated from a standard curve (Jain, 1986).

\section{Serum cholesterol}

The cholesterol of the serum was determined by using enzymatic endpoint method as described by Ahur et al. (2012). The absorbance of the sample was measured against the blank reagent within 60 minutes and the reading was taken at wave length of 520nm (Ahur et al., 2012).

\section{Total protein}

This was determined using Biuret method as described by Ahur et al. (2012). The reagent and serum was mixed and incubated for 30 minutes at $20-25^{\circ} \mathrm{C}$ and absorbance of the sample and that of the standard was measured against the blank at a wave length of $540 \mathrm{~nm}$. The total protein was calculated as follows:

$\mathrm{g} / \mathrm{d}=\frac{\text { Absorbance of sample } \times \text { Concentration }}{\text { Absorbance of standard }}$
$\mathrm{g} / \mathrm{d}=\frac{1}{\text { grams per decimeter. }}$

\section{Albumin}

The Bromo Cresol Green (BCG) method as described by Donmas (1971) were employed. The absorbance of the sample and the standard were taken against the reagent blank at a wave length of $620 \mathrm{~nm}$.

Albumin $(\mathrm{g} / \mathrm{d})$ concentration $_{=} \frac{\text { Absorbance of sample } \times \text { concentration }}{\text { Absorbance of standard } 1}$

\section{Aspartate transferase}

Concentration of the oxaloacetate hydrazoneformed with 2,4- dinitrophenylhydrazine was measured by absorbance it produces, $0.1 \mathrm{ml}$ of test samples was added to $0.5 \mathrm{ml}$ phosphate buffer containing q-oxoglutarate and $\mathrm{L}-$ aspartate. It was mixed and allowed to stand for 30 minutes at $37 \mathrm{oc} \quad 0.5 \mathrm{ml}$ solution containing 2, 4dinitrophenylhydrazine were added and allowed to stand for 20 minutes at $25^{\circ} \mathrm{C}$. Later $5 \mathrm{ml}$ solution hydroxide was added, mixed and the absorbance of the color produced was read using spectrophotometer and concentration was determined from Aspartate transferase (AST) activity table (Ahur et al., 2012)

\section{Alanine transferase}

Concentration of the oxaloacetate hydrazone formed with 2, 4 - dinitrophenylhydrazine was measured by absorbance it produces, $0.1 \mathrm{ml}$ of test sample was added to $0.5 \mathrm{ml}$ phosphate buffer containing $\mathrm{q}-$ oxoglutarate and $\mathrm{L}$ - aspartate. It was mixed and allowed to stand for 30 minutes at $37 \mathrm{oc} \cdot 0.5 \mathrm{ml}$ solution containing 2,4 dinitrophenylhydrazine was added and allowed to stand for 20 minutes at $25 \mathrm{oc}$. Later $5 \mathrm{ml}$ sodium hydroxide was added, mixed and the absorbance of using spectrophotometer and concentration was determined from Alanine transferase (ALT) activity table (Ahur et al., 2012).

\section{Calcium}

Lx20 system was used to dilute Ion Selective Electrode (ISE) methodology to measure calcium concentration in serum. The system will determine calcium concentration by measuring calcium ion activity in solution. The sample of buffer mixture contact the electrode, calcium ions complex with the ionophore at the electrode surface. The reference signal was used to calculate the analyzed concentration based on the Nernst equation (Ahur et al., 2012).

\section{Bicarbonate}

Bicarbonate reacts with Phosphoenolpyruvate (PEP) in the presence of Phosphoenolpyruvate Carboxylase (PEPC) to produce oxaloacetate and phosphate. This reaction occurs in conjunction with the transfer of a hydrogen ion from Nicotinamide Adenine Dinucleotide Hydrogenase (NADH) to oxaloacetate using MDH. The resultant of Nicotinamide Adenine Dinucleotide (NAD) causes a decrease in absorbance in the uv range $(320-400$ $\mathrm{nm})$. The change in absorbance was directly proportional to the concentration of bicarbonate in the sample being assayed (Ahur et al., 2012).

\section{Glucose}

Hexokinase catalyses the phosphorylation of glucose by adenosine triphosphate. G-6-PD was oxidized to 6phosphogluconate in the presence of NAD by the enzymes glucose -6- phosphate dehydrogenase (Ahur et al., 2012). 


\section{Sodium}

An ISE made use of unique properties of certain membrane materials to develop an electrical potential Electromotive Forces (EMF) for the measurement of ions in solution. The electrode has a selective membrane in contact with the both test solution and an internal filling solution (Ahur et al., 2012).

\section{Statistical analysis}

Analysis Of Variance (ANOVA) using the general linear model SAS (2000) was employed. Duncan's Multiply Range Test (DMRT) was used to indicate the significant diferences at level of $\mathrm{P}<0.05$.

\section{Ethical approval}

Federal College of Education, Kontagora has adopted the University of Ibadan institutional animal care and use committee which works on animal care and research ethics. The aim was to provide a platform geared towards educating the scientific world on global best practices as it concerns humane handling and use of laboratory/experimental animals for research purposes.

\section{RESULTS}

The serum glucose levels were 8.10, 8.27, 8.60, 9.07 and $7.57 \mathrm{mmol} / \mathrm{l}$ for the control, rice hull, groundnut hull, WS and sharp sand respectively. The mean values of this parameter indicated that WS and sharp sand had the highest and lowest serum glucose content of 9.07 and $7.57 \mathrm{mmol} / 1$ respectively. There was no significant ( $>0.05)$ difference in the serum glucose content for the broilers raised on the different bedding materials.

There was not a significant different $(p \leq 0.05)$ between treatment groups for values of serum cholesterol. However broilers raised on the rice hull and control grroups had insignificantly higher values than the other groups ( $>0.05$ ) (Table 1).

The albumin level of the birds raised on the sharp sand $(4.27 \mathrm{~g} / \mathrm{dl})$ was significantly $(\mathrm{p}<0.05)$ higher than the birds raised on WV $(3.20 \mathrm{~g} / \mathrm{dl})$. There was no significant difference $(p>0.05)$ between the mean values of the globulin levels of the birds reared on different bedding materials (Table 1).
There was significant difference $(\mathrm{p}<0.05)$ in the serum bicarbonate content of the broilers raised on the rice hull $(28.67 \mathrm{mmol} / \mathrm{l})$ having significantly higher $(\mathrm{p}<0.05)$ serum bicarbonate content than the birds reared on the WS ( $24.33 \mathrm{mmol} / \mathrm{l})$. Calcium contents in the serum showed no significant difference $(p>0.05)$ between the treatments (Table 1).

The serum sodium contents in control group (154.63 $\mathrm{mmol} / \mathrm{l}$ ) was significanly higher than the WS group $(112.90 \mathrm{mmol} / \mathrm{l}) \quad(\mathrm{p}<0.05)$. However no significant different with other treatments. No significant differences $(p>0.05)$ were recorded between the treatments about bilirubin and conjugated bilirubin contents (Table 1).

The serum levels of ALT in broilers were 3.30, 5.47, 4.50, 2.57 and 3.17iu/l whereas the levels of AST were $2.60,2.53,1.84,1.87$ and $2.27 \mathrm{iu} / 1$ for the birds raised on the control, rice hull, groundnut hull, WS and sharp sand respectively. There was no significant difference ( $p>0.05)$ in the levels of AST between the broilers reared in different treatments (bedding materials) but the level of ALT in the birds reared on the rice hull was significantly $(\mathrm{p}<0.05)$ higher than the birds raised on the WS and sharp sand (Table 1). Statistically, there were no significant differences $(p>0.05)$ in the heterophils and lymphocytes for the broilers raised on different bedding materials (Table 1).

There were significant differences $(\mathrm{p}<0.05)$ in the monocytes between birds raised on rice hull when compared with control and sharp sand; also, WBC was significantly higher $(\mathrm{p}<0.05)$ in broilers of control group when compared with other groups (Table 1). The RBC content were $2.05,1.95,1.88,1.93$ and $1.95 \mathrm{iu} / 1$ for the broilers that were reared on the control, rice hull, groundnut hull, WS and sharp sand respectively. The recorded the significantly highest RBC content was established in birds reared on sharp sand $(\mathrm{p}<0.05)$ when compared other bedding materials (control, rice hull, groundnut hull) and insiginificantly higher than WS group (Table 1).

The $\mathrm{Hb}$ content of the birds raised on the control $(12.20 \mathrm{iu} / \mathrm{l})$ was significantly higher $(\mathrm{p}<0.05)$ than those for the other treatments $(6.02,5.62,7.46$ and $7.66 \mathrm{iu} / \mathrm{l})$.

There was no significant difference in PCV level ( $>0.05$ ) between the broilers reared on different bedding materials. 
Table 1. The effect of different bedding materials on hematological and serum biochemical parameters of broiler chicken (Arbor acre) between February and April 2018 at research and teaching farm of federal college of education, Kontagora Niger state, Nigeria

\begin{tabular}{|c|c|c|c|c|c|}
\hline Parameters & Control & Rice Hull & Groundnut Hull & Wood Shaving & Sharp Sand \\
\hline Heterophils (iu/l) & $53.67 \pm 7.26^{\mathrm{a}}$ & $50.33 \pm 11.35^{\mathrm{a}}$ & $55.00 \pm 2.65^{\mathrm{a}}$ & $48.00 \pm 7.81^{\mathrm{a}}$ & $44.67 \pm 6.17^{\mathrm{a}}$ \\
\hline Monocytes (iu/l) & $1.67 \pm 0.88^{\mathrm{a}}$ & $6.00 \pm 1.53^{\mathrm{b}}$ & $3.00 \pm 1.15^{\mathrm{ab}}$ & $4.33 \pm 1.45^{\mathrm{ab}}$ & $1.33 \pm 0.67^{\mathrm{a}}$ \\
\hline Lymphocytes (iu/l) & $44.67 \pm 6.39^{\mathrm{a}}$ & $43.67 \pm 10.48^{\mathrm{a}}$ & $42.00 \pm 2.08^{\mathrm{a}}$ & $47.67 \pm 9.24^{\mathrm{a}}$ & $54.00 \pm 5.51^{\mathrm{a}}$ \\
\hline Haemoglobin (iu/l) & $12.20 \pm 0.85^{\mathrm{b}}$ & $6.02 \pm 1.62^{\mathrm{a}}$ & $5.62 \pm 0.42^{\mathrm{a}}$ & $7.46 \pm 1.39^{\mathrm{a}}$ & $7.66 \pm 1.03^{\mathrm{a}}$ \\
\hline White blood cell (iu/l) & $66.71 \pm 3.41^{\mathrm{b}}$ & $22.0^{1 \pm} 13.68^{\mathrm{a}}$ & $13.16 \pm 8.10^{\mathrm{a}}$ & $24.95 \pm 15.60^{\mathrm{a}}$ & $29.73 \pm 14.62^{\mathrm{a}}$ \\
\hline Red blood cell (iu/l) & $2.05+0.22^{\mathrm{a}}$ & $1.95+0.32^{\mathrm{a}}$ & $1.88+0.42^{\mathrm{a}}$ & $2.12+0.50^{\mathrm{ab}}$ & $2.92+0.23^{\mathrm{b}}$ \\
\hline Packed cell volume $(\%)$ & $19.78 \pm 1.56^{\mathrm{a}}$ & $12.71 \pm 4.00^{a}$ & $16.18 \pm 3.73^{a}$ & $17.57 \pm 5.44^{\mathrm{a}}$ & $17.28 \pm 4.78^{a}$ \\
\hline Mean cell volume \% (MCV) & $107.67 \pm 6.81^{\mathrm{a}}$ & $112.33 \pm 2.73^{\mathrm{a}}$ & $112.00 \pm 4.00^{\mathrm{a}}$ & $113.00 \pm 8.89^{\mathrm{a}}$ & $120.67 \pm 2.03^{\mathrm{a}}$ \\
\hline Glucose level (mm02/I) & $8.10 \pm 0.62^{\mathrm{a}}$ & $8.27 \pm 0.62^{\mathrm{a}}$ & $8.60 \pm 0.09^{\mathrm{a}}$ & $9.07+0.45^{\mathrm{a}}$ & $7.57 \pm 0.67^{\mathrm{a}}$ \\
\hline Total protection level (g/dl) & $6.80 \pm 0.20^{\mathrm{a}}$ & $6.73 \pm 0.29^{\mathrm{a}}$ & $6.87 \pm 0.09^{\mathrm{a}}$ & $6.47 \pm 0.33^{\mathrm{a}}$ & $6.63 \pm 0.33^{\mathrm{a}}$ \\
\hline Albumin level (g/dl) & $3.50 \pm 0.31^{\mathrm{a}}$ & $3.53 \pm 0.17^{\mathrm{a}}$ & $3.77 \pm 0.35^{\mathrm{ab}}$ & $3.20 \pm 0.06^{\mathrm{a}}$ & $4.27 \pm 0.90^{\mathrm{b}}$ \\
\hline Globulin level (g/dl) & $30.97 \pm 11.40^{\mathrm{a}}$ & $35.20 \pm 1.89^{\mathrm{a}}$ & $30.33 \pm 6.67^{\mathrm{a}}$ & $39.20 \pm 5.77^{\mathrm{a}}$ & $43.67 \pm 6.17^{\mathrm{a}}$ \\
\hline Aspartate transferase (iu/l) & $2.60 \pm 0.57^{\mathrm{a}}$ & $2.53 \pm 0.38^{\mathrm{a}}$ & $1.84 \pm 0.06^{\mathrm{a}}$ & $1.87 \pm 0.08^{\mathrm{a}}$ & $2.27 \pm 0.42^{\mathrm{a}}$ \\
\hline Alanine transferase level (iu/l) & $3.30 \pm 0.25^{\mathrm{a}}$ & $5.47 \pm 1.16^{\mathrm{b}}$ & $4.50 \pm 0.20^{\mathrm{ab}}$ & $2.57 \pm 0.33^{\mathrm{a}}$ & $3.17 \pm 0.18^{\mathrm{a}}$ \\
\hline Total bilirubin level (mg/dl) & $0.77 \pm 0.010^{\mathrm{a}}$ & $0.60 \pm 0.10^{\mathrm{a}}$ & $0.68 \pm 0.08^{\mathrm{a}}$ & $0.62 \pm 0.05^{\mathrm{a}}$ & $0.06 \pm 0.09^{\mathrm{a}}$ \\
\hline Conjugated bilirubin level (mg/dl) & $0.09 \pm 0.33^{\mathrm{a}}$ & $0.11 \pm 0.07^{\mathrm{a}}$ & $0.10 \pm 0.05^{\mathrm{a}}$ & $0.14 \pm 0.01^{\mathrm{a}}$ & $0.17 \pm 0.06^{\mathrm{a}}$ \\
\hline Calcium level (mg/dl) & $8.57 \pm 0.87^{\mathrm{a}}$ & $7.73 \pm 0.12^{\mathrm{a}}$ & $8.13 \pm 0.59^{\mathrm{a}}$ & $8.13 \pm 0.33^{\mathrm{a}}$ & $9.43 \pm 0.72^{\mathrm{a}}$ \\
\hline Bicarbonate level (mmol/l) & $27.33 \pm 0.88^{\mathrm{ab}}$ & $28.67 \pm 0.88^{\mathrm{b}}$ & $26.33 \pm 1.20^{\mathrm{ab}}$ & $24.33 \pm 1.55^{\mathrm{a}}$ & $26.00 \pm 1.00^{\mathrm{ab}}$ \\
\hline Sodium level (mmdl/l & $154.63 \pm 1.90^{\mathrm{b}}$ & $124.93 \pm 12.95^{\mathrm{ab}}$ & $127.833 \pm 18.41^{\mathrm{ab}}$ & $112.90 \pm 1.55^{\mathrm{a}}$ & $140.20 \pm 5.23^{\mathrm{ab}}$ \\
\hline Cholesterol level (mmol/dl) & $4.37 \pm 0.53^{\mathrm{ab}}$ & $4.47 \pm 0.38^{\mathrm{ab}}$ & $3.67 \pm 0.023^{\mathrm{a}}$ & $3.73 \pm 0.19^{\mathrm{a}}$ & $3.57 \pm 0.09^{\mathrm{a}}$ \\
\hline
\end{tabular}

Data are presented as (mean $\pm \mathrm{SEM}) .{ }^{\mathrm{a} \text { ab, b }}$ within the same row with different superscripts declare significant differences $(\mathrm{P} \leq 0.05)$.

\section{DISCUSSION}

Similar haematological values obtained from broiler chickens reared on different bedding materials with those in the control group is indicative of the bedding materials used. According to Rath et al. (2006), RBC, WBC and PCV values in broilers were not affected, which is an agreement with present findings.

Similarly, Cetin et al. (2006) reported that supplementation of humic acid to laying hens had no effects on WBC and PCV but affected on RBC and $\mathrm{Hb}$ levels. However Banaszkiewicz and Drobnik (1994) reported that $\mathrm{Hb}, \mathrm{PCV}$ and $\mathrm{RBC}$ were observed to increase in rats treated with humic acid. The inconsistency of results in the various studies might be attributed to the composition and nature of the bedding materials.
The increase of $\mathrm{Ca}$ and $\mathrm{Na}$ levels in blood serum caused by effect of different bedding materials in this studied agreed with findings of Boling et al (2001), Abdo and Zeinb (2004) which is attributed to the lowering of gastrointestinal tract $\mathrm{pH}$, which increases the absorption of the minerals from the gut into the blood stream. Improvement in the utilization of calcium and sodium by organic acids supplementation which was revealed by Boling et al. (2001). Increase in blood calcium of broiler chicks fed on dietary acidifier was observed by Abdo and Zeinb (2004) . Furthermore Kishi et al. (1999) reported that dietary acetic acid prevented osteoporosis, through the reduction in bone turnover, as it enhanced intestinal $\mathrm{Ca}$ absorption by improving Ca solubility in ovariectomized rats. 
The levels of some essential minerals (such as $\mathrm{Ca}, \mathrm{Al}$ and $\mathrm{Fe}$ ) in serum, liver and muscles increased after humate feeding (Stepchenko et al., 1991).

The result of aspartate aminotransferase and alanine aminotransferase means that broiler chickens could tolerate the effect of different bedding materials without any deleterious effects on liver functions. Abdel-Azeem et al. (2000) reported that level of aspartate aminotransferase was reduced, although alanine aminotransferase was significantly affected by bedding materials which is not in agreement with Abdel-Azeem et al.(2000) in this studied.

These findings corroborates the conclusion that when birds are reared on alternative bedding materials, their performance is equal to or worse than that of birds reared on WS (Benabde and Ayach, 1996; Grimes et al., 2002). Contradictory results have been reported that broilers performance and welfare found to be improved when the birds are reared on WS over other materials used as bedding, (Neme et al., 2000; Tasistro et al., 2007) reported significantly lower weight gained when birds were reared on wheat straw relative to WS.

Also, performance of flocks raised on rice hulls was reported to be lower when compared with WS (Garcia et al., 2010). The enhanced performance of the birds on the sharp sand over other bedding materials could be attributed to the possession of good physical properties such as fines and high absorbance capacity due to its pervious nature which allowed for easy movement of liquid and air in addition to easy drying. Sharp sand provides a suitable condition that can encourage social behavior such as sand bathing which has been reported to help reducing aggressive behavior and improves general leg health conditions, leading to better mobility and better flock welfare (Shields et al., 2004). Sharp sand also offers a high option for use as bedding material in poultry production, particularly in the area of study as it meets the most selection criteria listed by Garcia et al. (2010) such as availability, accessibility, ease of handling, cheapness, low fermentation, environmental impact, ability of avoiding compacting, amongst others. Gracia et al. (2010) had reported that sand litter was four times heavier than WS posing potential problems in handling and transportation. However, sand allows producers to rear multiple flocks while only removing small portions of litter, which could compensate for these aspects and make it a convenient bedding source (Bowes et al., 2003).

The levels of glucose for the broilers raised on the different bedding materials of this studied were below the normal levels of glucose concentration in the majority of birds which is usually in range of $11.1-27.8 \mathrm{mmol} / \mathrm{L}$ which is not in agreement of Coles et al. (1970) and Hrabčáková et al. (2014) findings may be due to the poor absorption of the feeds by broilers. They reported that glucose values that were in the normal range for pheasants. It is also documented by Lloyd and Gibs (2006) in range of $19.5-20.08 \mathrm{mmol} / \mathrm{L}$ and Nazifi et al. (2012) reported in range of $2.6 \mathrm{mmol} / \mathrm{L}$ in pheasants females.

The values of cholesterol for the broilers were within the standard range of values in domestic fowl which is 3.55 to $10.25 \mathrm{mmol} / \mathrm{L}$ reported by Sugiharto (2014). The finding of this present studies is in accordance with the findings of Sugiharto (2014). As already been published, the wide variation in cholesterol levels between species of birds may be due to the circadian rhythms, effects of diet (Harr, 2002; Villagrá et al., 2011) gender and age (Meluzzi et al., 1992). However, (Hrabčáková et al., 2014) reported that the increases in the cholesterol levels could be due to increased biosynthesis and accumulation of egg yolk in the layers, which is not peculiar with broilers.

The values for total protein content in the majority of birds fall was in range of 30-50 g/L, (Lloyd and Gibson, 2006; Nazifi et al., 2012). Significant differences in albumin and serum total protein among females and males during breeding season might be due to the egg production that can influence on concentration of the blood proteins (Schmidt et al., 2007). The serum protein levels in the birds of present studies reared on the different bedding materials were under the reported normal range which agreed with findings of Lloyd and Gibson (2006); Nazifi et al (2012). Serum total protein and albumin are directly related to protein intake and feed quality. Serum proteins are involved in the formation of immunoglobins responsible for the development of antibodies. High or low serum globulin content may implicate a better disease resistance and immune response of chickens reported by Abdel-Fattah et al. (2008) which was observed in this present studied when compared with control.

Generally, Biochemical parameters can be used as physiological indicators in birds. Their values are influenced by species, age, sex, season, geographic region, nutrition, and physiological condition (Paria, 2014). They are also indicators of the health of birds housed in cage deep liters systems. Parameters such as total protein, albumin, cholesterol, glucose, calcium, and aspartate aminotransferase are commonly measured as biochemical characteristics of poultry (Hrabčáková et al., 2014). It has been noted that significant changes in the serum biochemical parameters can be related to the both pathological and nutritional status of individual animals (Aldu-hafeez et al., 2009) 
The values of examined hematological parameters were according to the reported range of broilers (Talebi et al., 2005). The measured parameters of present experiment were age dependent which are disagrees with findings of Talebi et al. (2005) in broiler chickens. The changes in $\mathrm{Hb}$ concentration, erythrocyte count, haematocrit level and differential leukocytes may indicate stress as reported by Hrabčáková et al. (2014), while the changes in erythrocyte, $\mathrm{Hb}$ and pack cell volume may reflect an alteration of energy status in chickens as reported by Karamanlis et al. (2008) and Alabi et al. (2015). Aside from the physiological and nutritional aspects, haematological variables can also be used as an indicator of health in birds, (Hrabčáková et al., 2014). Indeed, several factors have been obtained that influence on haematological variables including species, age, sex, environment, nutrition, infection and physiological conditions, (Hrabčáková et al., 2014). Leukocytes are cells of the immune system that protect the body against infections. The findings of WBC in this studied agreed with Sugiharto et al. (2014) findings due to the high numbers of leukocytes in control when compared with bedding materials. This may due to the lack of comfort leading to stress in the control. High number of leukocytes seems therefore to imply in a superior ability of chickens to respond to infections. However, this assumption may be ambiguous as high number of leukocytes may also indicate stress (Sugiharto et al., 2014).

\section{CONCLUSION}

Since, serum biochemical parameters can indicate and influence the behavior and health conditions of birds, it is important that alternative bedding materials be investigated for their influences on these parameters in order to determine if they can replace the conventionally known bedding materials such as WS that are becoming scarce in recent times. The compatibility of the values of the haematological parameters evaluated for the other bedding materials to those of WS suggest that they can successfully be utilized in the rearing of broilers without detrimental effects on the health and physiology of the birds.

From the findings of the research, rice hull, groundnut hull and sharp sand can be effectively used as alternative bedding materials to WS without detrimental effects on the physiology of broilers, particularly in the locality of Kontagora and its environs where rice and groundnut are intensively produced, and sharp sand can be sourced with ease and at cheaper cost. Rice hull, groundnut hull and sharp sand can function effectively in this regard and performance of broilers would be maintained and even improve as associated with WS. Sharp sand presents the best alternative as it is not and may not be in shortage, and does not have unnecessary competition for other uses that limit its availability as rice and groundnut hulls, which face serious competition as livestock feeds during the dry season.

\section{DECLARATIONS}

\section{Authors contributions}

Dr. Gana James. Carried out the main work, which were the blood analysis for hematological and serum biochemical parameters, compilation and discussion of the results. He has gone through the work and approved for publication. Dr. Adekojo S.A: Collected the blood samples for hematological and serum biochemical analyses. He has read through the research work and recommended the final manuscript for publication. Mr. Danwake J.G: Carried out statistical analysis of obtained results. He has read through and recommended the final manuscript for publication. Mr. Zarma Adamu: Restrained the birds for the collections of blood samples and assisted the corresponding author in the compilation and discussion of the results. He has read through and approved the final manuscript for publication. Mr. Zakari Mamman: Prepared the brooding house, feeding of the birds, daily supplied of water, administration of vaccines/medications and changed the bedding materials. He has read through and approved the final manuscript for publication.

\section{Consent to publish}

The authors have given permission for the manuscript should be published.

\section{Competing interests}

There was no conflict of interest reasons being that research results were not influenced by external factors or any scientific misconduct and was free of bias. Thus, professional judgments and objectives of the research were not harmed.

\section{REFERENCES}

Abdel - Azeem F, El-Hommosany YM and Ali GM (2000). Effect of citric acid in diets with different starch and fiber levels on productive performance and some physiological traits of growing rabbits. Egyptian Journal of Rabbit Science, 10: 121-145. 
Abdel-Fattah SA, El-Sanhoury MH, El-Mednay NM and AbdelAzeem F (2008). Thyroid activity, some blood constituents, organs morphology and performance of broiler chicks fed supplemental organic acids. International Journal of Poultry Science, 7: 215-222. Doi:10.3923/ijps.2008.2015.222

Abdo M and Zeinb A (2004). Efficacy of acetic acid in improving the utilization of low protein-low energy broiler diets. Egyptian Poultry Science, 24: 123-141.

Ahu VM, Agada PO and Saganuwan SA (2012). Estimating the Plasma and Serum Activity Levels of Aspartate Aminotransferase and Alanine Aminotransferase, in Live Animals Using Regression Model. Trends in Applied Sciences Research, 7: 748-757. Doi:10.3923/tasr.2012.748.757

Akpodiete OJ and AD Ologbodo (1998). The nutritive value of maggot meal in broiler Chicks in nutrients retention, haematology and serum chemistry. Proceedings of the third Annual Conference of Animal Science Association of Nigeria, 39, 18-21, 1998, Lagos, pp. 29-39. Doi:10.3923/ajpsaj.2016.96.103

Alabi AJ, Ng'ambi JW, Mbajiorgu EF, Norris D and Mabelebele M (2015). Growth and haematological response of indigenous Venda chickens aged 8 to 13 weeks to varying dietary lysine to energy ratios. Journal of Animal Physiology and Animal Nutrition, 99: 436-441. Doi: 10.1111/jpn.12277.

Aldu-hafeez SM, Suhail ER, Durrani Dawood Jani I, Ahmad N Chand and Altafur Rehman (2009). Effect of different types of locally available litters materials on the performance of bird's chicks. Sahad journal of agriculture, 25(4): 581-586.

Banaszkiewick W and Drobnik M (1994). The influence of natural peat and isolated humic acid solution on certain indices of metabolism and of acid-base equilibrium in experimental animals. Roczniki Państwowego Zakładu Higieny, 45: 353-60. https://www.ncbi.nlm.nih.gov/pubmed/7792525

Benabdeljelil K and Ayachi A (1996). Evaluation of alternative litter material for poultry. Journal of Applied Poultry Research, 5: 203-205.Doi:http:/dx.doi.org/10.5772/54068

Boling SD, Frankenbach JL, Snow CM, Parsons CM and Baker DH (2001). The effect of citric acid on the calcium and phosphorus requirements of chicks fed Corn -soybean meal diets. Poultry Science, 80: 783-788.

Bowes VA, Hess JB, Bilgili SF, Blake JP, Eckman MK and Guertal EA (2003). Nutrient buildup in sand litter. Journal of Applied Poultry Research, 12: 522- 5235

Bowes VA, Julian RJ and Stirtzinger T (1989). Comparison of serum biochemical profiles of male broilers with female broilers and White Leghorn chickens. Can. Journal Veterinary Research, 53:7-11.

Cetin M, Cetin B and Guclu BK (2006). Effect of humate and organic acids supplementation to ration on some haematological parameters in laying hens. Ankara Üniversitesi Veteriner Fakültesi Dergisi, 53: 165-168

Coles B, J Biely and BE March (1970). Vitamin A deficiency and Eimeriaacervulinainfection in the chick. Poultry Science, 49:1295. Doi:10.3923/ajas.2007.26.32
Dacies JV and Lewis SM (1995). Practical haematology, 8th Edition Churchill living standard, p. 609. Doi: 10.4236/ce.2012.33048

Dacie JV and Lewis SM (1984). Practical haematology. 6th Edition. Churchill Livingston Edinburgh. Pp. 24-36.

Donmas G (1971). Toxicological study on the edible larva cirinaforda- Africa. Available www.ajol,info/../42513

Garcia R, Almeida PI, Caldara FR, Näas IA, Pereira DF, Freitas LW and Graciano J (2010). Effect of the litter material on drinking water quality in broiler production. Revista Brasileira de Ciência Avícola, 12:165-169. Doi:http://dx.doi.org/10.1590/S1516-635X2010000300005.

Grimes JL, Smith J and Williams CM (2002). Some alternative litter materials used for growing broilers and turkeys. World's Poultry Science Journal, 58: 515-525.

Harr KE (2002) Clinical Chemistry of Comparism Avian Specie: A review. Veterinary Clinical Pathology, 31:140-151. Doi:10.1111/j.1939-165X.2002.tb00295.

Hrabčáková P, Voslálová E, Bedáňová I, Pištjková V, Chloupek J and Večerek V (2014). Haematological and biochemical parameters during the laying period in common pheasant hens housed in enhanced cages. The Scientific World Journal. Doi:http://dx.doi.org/10.1155/2014/364602.

Horsted K and Hermansen JE (2007). Whole wheat versus mixed layer diet as supplementary feed to layers foraging a sequence of different forage crops. Animals, 1(4):575-585. Doi:https://doi.org/10.1017/S175173110769418X

Albokhadaim I (2016). Effect of Aqueous Extract of Green Tea (Camellia sinensis) on Hematology and Oxidative Stress Biomarkers in Rats Intoxicated with Carbon Tetrachloride. Journal of Biological Sciences, 16: 49-57. Doi:10.3923/jbs.2016.49.57

Jain I (1986). Haematological reference interval for indian Leopards (Panthera pardus). Veterinary world, 1(6): 173174.

Jurani M, Hyboh P, Zeman M, Lamosora D, Kost'al L and Blazicek P (2004). Post-hatching dynamics of plasma Biochemistry in free living European starling (Sturnusvulganis). Comparative Biochemistry and Physiology, 138:89-95). Doi:10.1016/j.cbpb.2004.03.005

Karamanlis X, Fortomaris P, Arsenos G, Dosis I, Papaioannou D, Batzios C and Kamarianos A (2008). The effect of a natural zeolite (Clinoptilolite) on the performance of broiler chickens and the quality of their litter. AsianAustralasian Journal of Animal, Doi:https://doi.org/10.5713/ajas.2008.70652

Kishi M, Fukaya M, Tsukamoto Y, Nagasawa T, Kakehana K and Nishizawa N (1999). Enhancing effect of dietary vinegar on the intestinal absorption of calcium in overiectomized rats. Bioscience Biotechnology Biochemistry 63: 905-910. Doi: https://doi.org/10.1271/bbb.63.905

Krasnodêbska-Depta A and Koncickia A (2000). Physiological values of selected serum biochemical indices in broiler chickens. Medycyna Weterynaryjna, 56: 456-460. Doi:10.3409/fb60_1-2.65-70 
Lloyd S and Gibson JS (2006). Haematology and biochemistry in healthy young pheasants and red-legged partridges and effects of spironucleosis on these parameters. Avian Pathology, $35(4)$ : 335-340. Doi:https://doi.org/10.1080/03079450600821794

Melluzi A, Primiceri G, Giordani R and Fabric G (1992). Determination of blood constituent references values in Broiles. Poultry Science, 71:337-345.

Monira KN, Islam MA, Alam MJ and Wahid MA (2003). Effect of litter material on broiler performance and evaluation of manurial value of used litter in late autumn. AsianAustralasian Journal of Animal Sciences, 16: 555-557.

Nazifi S, Mosleh N, Ranjbar VR and Khordadmehr M (2012). Reference values of serum biochemical parameters in adult male and female ring-necked pheasants (Phasianuscolchicus). Comparative Clinical Pathology, 21(5): 981-984. Doi: 10.1007/s00580-0111212-1219

Neme R, Sakomura NK, Oliveira MDS, Longo FA and Figueiredo NA (2000). Adição de gesso agrícolaemtrêstipos de cama de aviárionafixação de nitrogêniodesempenho de frangos de corte. Ciência Rural, 30: 687-692. Available at: http://www.scielo.br/pdf/cr/v30n4/a22v30n4.pdf

Niger State Bureau de Statistics (2011): Niger State Planning Commission. Facts and Figures about Niger State: 2011 Edition.

Onifade AA (1998). Proposing fortification of foods with yeast for optimal nutrition value and salubrious effects. Nutrition Food Science, 98: 223-226. Doi: 10.1108/00346659810215163

Paria A (2014). Consideration of blood serum biochemical parameters of yellow fin-sea bream (Alantopagnuslatus Houttuyn, 1872) and Orange-spotted grouper (Epinepheluscoioides Hamilton, 18822). Advances in biological chemistry, scientific research. Doi: 10.4236/abc.2014.46046

Pedersen K, Hald B, Skovgard H, Bang DDK, Dybdahl J and Jespersen JB (2000). Flies and Compylobacter infection of broiler flock. Doi:10.3201/eid1008.040129

Rajman M, Jurani M, Lamosova D, Macojora M, Sedlackora M, Kostal L, Jezora D and Vyboh P (2006). Effect of feed restriction of plasma biochemistry in growing meat type chickens (Gallusgallus). Comparative Biochemistry \& Physiology, 145:363-371. Doi:10.1016/j.cbpa.2006.07.004

Ross JG, Christie G, Halliday WG and Jones RM (1978). Haematological and blood chemistry "Companion values for clinical pathology in poultry. Veterinary Records, 102: 29-31. DOI:10.1136/vr.102.2.29

Rath NC, Huff WE and Huff GR (2006). Effect of humic acid on broiler chickens. Poultry Science, 85: 410- 414. DOI:10.1093/ps/85.3.410

Static Analysis Symposium (SAS) (2000). University of Santa Barbara, USA Sponsored by the Santos, cis.ksu.edu./sas/home.html.

Schmidt EMDS, Paulillo AC and Dittrich RL (2007). The effect of age on hematological and serum biochemical values on juvenile ring-necked pheasants
(Phasianuscolchicus). International Journal of Poultry Science, 6 (6): 459- 461.

Shields SJ, Garner JP and Mench JA (2004). Dustbathing by broiler chickens: a comparison of preference for four different substrates. Applied Animal Behaviour Science, 87: 69-82.

Shlosberg A, Bellaiche M, Zeitlin G, Yaacobi M and Cahaner A (1996). Haematocrit values and mortality from ascites in cold-stressed broiler from parents selected by haematocrit. Poultry Science, 75: 1-5. Doi:10.3382/ps.0750001

Spinu M, Spinu O and Degen AA (2010). Haematological and immunological variables in a domesticated and wild subspecies of ostrich (Struthio camelus). Britain Poultry Science, $\quad 40: \quad 613-618$ Doi:https://doi.org/10.1080/00071669986981

Stepchenko LM, Zhorina LV and Kravtsova LV (1991). The effect of sodium humate on metabolism and resistance in highly productive poultry (in Russain). Nauchnye Doklady Vysshei Shkoly. Biologicheskie Nauki, 10: 90-95.

Sugiharto S, Hedemann MS and Lauridsen C (2014). Plasma metabolomic profiles and immune responses of piglets after weaning and challenge with E. coli. Journal of Animal Science and Biotechnology, 5: 17. Doi:https://doi.org/10.1186/2049-1891-5-17

Talebi A, Asri-Rezaei S, Rozeh-Chai R and Sahraei R (2005). Comparative studies on haematological values of broiler strains (Ross, Cobb, Arbor-acres and Arian). International Journal of Poultry Science, 4: 573-579. Doi:10.3923/ijps.2005.573.579

Tasistro AS, Ritz CW and Kissel DE (2007). Ammonia emissions from broiler litter response to bedding materials and acidifiers. British Poultry Science, 48: 399 - 405. Doi:https://doi.org/10.1080/00071660701473865

Tietz NW (1995). Clinical guide to laboratory tests. 3rd edition. W.B Saunders company. Philadelphia, USA, pp. 518-519.

Villagrá A, Olivas I, Benitez V and Lainez M (2011). Evaluation of sludge from paper recycling as bedding material for broilers. Poultry Science, 90: 953-957. Doi:10.3382/ps.2010-00935 